CZU: 81'367’37

https://doi.org/10.52505/lecturi.2021.05.07

\title{
SUBIECTIVITATEA ENUNȚĂRII
}

\author{
Alexandru COSMESCU \\ Institutul de Filologie Română „Bogdan Petriceicu-Hasdeu”, Chișinău
}

Rezumat. Atitudinea față de subiectivitate în disciplinele umaniste contemporane este, paradoxal, una de ezitare sau evitare. Tendința este de a cerceta doar ceea ce apare drept „obiectiv”. Cu toate acestea, o abordare a limbajului care nu ține cont de ancorarea lui în subiectivitate ratează aspecte esențiale. In lucrarea de fațăa am propus o reevaluare a unui studiu clasic al lui Emile Benveniste și, pornind de la intuițiile lui și ale lui Oswald Ducrot, am oferit un exemplu de analiză a urmelor subiectivității într-un fragment de text, arătând modul în care luarea în calcul a subiectivității enunțiative permite o interpretare complexă şi adecvată a enunțului.

Cuvinte-cheie: subiectivitate, enunțare, discurs, locutor, enunțiator, polifonie.

Abstract. The attitude towards subjectivity in contemporary humanistic disciplines is, paradoxically, one of hesitation or avoidance. The tendency is to carry research only on what appears as "objective". At the same time, approaching language without taking into account the fact it is anchored in subjectivity misses essential aspects. In the present paper, I proposed a reevaluation of a classic paper by Emile Benveniste and, taking his and Oswald Ducrot intuitions as a starting point, I offered a sample of analysis of traces of subjectivity in a text fragment, showing how taking into account enunciative subjectivity allows a nuanced and adequate interpretation of the utterance.

Keywords: Subjectivity, Utterance, Discourse, Speaker, Enunciator, Polyphony.

Atitudinea față de subiectivitate în disciplinele umaniste este, paradoxal, una de ezitare sau evitare. Ca cercetători, avem o anumită frică de subiectivitate - atunci când cercetăm ceva, luăm ceea ce cercetăm drept obiect - drept ceva ce poate fi ,pus în față” și descris sub aspect structural. Or, orice încercare de a descrie subiectivitatea prin transformarea ei în obiect o ratează. Din acest motiv, mai mulți cercetători care urmăresc fenomenul subiectivității în limbaj îl abordează fie sub aspectul structurilor, fie sub cel al urmelor lăsate de subiectivitate - dar nu trebuie neglijat faptul că subiectivitatea întrupată și situată este sursa primară a limbajului, iar orice act de limbaj este ancorat într-o subiectivitate. O abordare ce neglijează 
acest fenomen riscă să fie unilaterală. Mai mult decât atât, în calitate de lingviști suntem noi înșine subiecți; subiectivitatea este presupusă de însuşi faptul că noi suntem cei care examinăm un fenomen sau îl privim dintr-o perspectivă sau alta, în baza backgound-ului pe care îl avem. Or, specificul subiectivitătii ca transcendental este anume faptul că o neglijăm: subiectivitatea este condiția de posibilitate pentru prezența oricărui „fapt obiectiv”, dar a o examina pe ea însăși ca și cum ar fi un obiect ratează anume felul în care suntem subiecți. Respectiv, pentru a putea vorbi despre limbaj ținând seama de felul în care limbajul este ancorat în subiectivitate, avem nevoie de un mod de a privi care să nu o neglijeze și, în același timp, să nu o transforme în altceva.

Locus classicus al discuțiilor despre subiectivitate în limbaj din perspectiva lingvisticii este articolul din 1958 al lui Emile Benveniste, Subiectivitatea în limbă (Benveniste, 1971, pp. 223-230). Benveniste pornește de la o chestionare a tezei, repetate atât de des încât pare de la sine înțeleasă, că limba ar fi un instrument de comunicare. Conform lingvistului francez, pe de o parte, interpretarea comunicării drept transmisie de informație ratează specificul limbii; pe de altă parte, metafora „,instrumentului” este o simplificare excesivă care, prin separarea „omului” de „limbă”, creează imaginea falsă a posibilității separării lor reale. Însă, după cum remarcă Benveniste, ,ceea ce găsim în lume este un om care vorbește, un om care vorbește cu un alt om, iar limba oferă însăși definiția omului” (Benveniste, 1971, p. 224), ca aspect inseparabil al său, în bună tradiție aristotelică și heideggeriană a definirii omului prin logos - limbă sau discursivitate. Din această perspectivă, limba nu este un instrument separabil pe care „omul” ca entitate independentă de limbă l-ar putea folosi, ci parte a esenței umanului. Conceperea limbii drept „instrument pentru comunicare" conduce la construirea unei reprezentări false despre „om” ca ceva „deja dat” independent de limbă.

Benveniste nu încearcă să nege existența fenomenului pe care îl numim comunicare sau schimb de informație, deși accentuează faptul că a-l prezenta în termeni de „schimb” sau ,instrument” este problematic, ci să chestioneze condițiile lui de posibilitate. În primul rând, circumstanțele în care putem vorbi despre comunicare sunt cele ale vorbirii sau discursului - nu cele ale limbii; și chiar și în cazul discursului, a-l interpreta pur și simplu drept comunicare riscă să treacă cu vederea o serie de aspecte specifice lui. Însă interogația lui Benveniste vizează ceva și mai fundamental: ce anume în limbă face posibilă comunicarea la nivelul discursului, iar pista pe care o propune pentru formularea unui răspuns este că subiectivitatea însăși este instituită de limbă. Respectiv, felul în care concepe Benveniste subiectivitatea nu este ca „simţire de sine”, nici în sensul conţinutului afectiv, somatic și intelectual de moment, nici în sensul „faptului de a simţ" ca atare, ci ca o instanță care transcende orice experiență de moment. Conform 
analizei lui Benveniste - confirmată, din altă perspectivă, de Martin Heidegger (Heidegger, 1971, passim) - limba însăși este cea care instituie subiectivitatea în acest sens pregnant și transcendental. Cu o formulă a lui Benveniste citată adesea, „este «eu» cel care spune «eu»” (Benveniste, 1971, p. 224). Însă această afirmație solicită o interpretare atentă: lingvistul francez nu se referă la un fapt-de-a-fi-eu anterior limbajului care s-ar exprima în limbaj, ci de o instituire a eului prin limbaj, prin faptul-de-a-spune-eu. Iar această dimensiune a subiectivității este profund relațională, Benveniste înscriindu-se în tradiția dialogică a unui Martin Buber, Mihail Bahtin sau Emmanuel Levinas: a fi eu presupune un tu căruia mă adresez. Obținem „conștiința de sine” în calitate de subiect - faptul-de-a-fi-și-de-a-ne-simțidrept-eu - doar prin contrastul în raport cu un tu pe care îl avem în faţă și, după cum remarcă Benveniste, acest $t u$ trebuie să poată spune el însuşi ,eu” despre sine. Această „polaritate reversibilă a persoanelor”, în care un „eu” este de fiecare dată „eu al unui tu” exterior „mie”, care poate el însuși să-și asume propriul fapt-de-afi-eu-al-unui-tu, este fenomenul primar al limbii, cel care face posibil ca fiecare dintre noi să ne asumăm și constituim propria subiectivitate. „Comunicarea” devine posibilă doar pe baza acestei structuri asimetrice și non-egale, dar reciproce și reversibile, în care fiecare termen îl transcende pe celălalt.

Benveniste oferă o trecere în revistă a mai multor fapte de limbă ce reflectă această structură, în primul rând pronumele personale. Conform analizei lui pertinente, sensul primar al pronumelui „eu” ține de însuşi faptul vorbirii în momentul prezent: „,eu” este, de fiecare dată, cel care formulează un enunt,, iar „tu” - cel căruia îi este adresat enunțul respectiv. Enunțând ceva și adresându-ne cuiva, ne asumăm faptul-de-a-fi-eu - deci subiectivitatea este constituită în discurs, cu mijloace discursive, și își capătă sensul doar prin referire la discurs. La fel și în cazul deicticelor: „acesta, aici, acum” și corelatele lor „acela, acolo, atunci” își capătă sensul doar prin raportare la faptul concret al vorbirii: nu un prezent abstract, al unui flux temporal independent de locutor, ci însuși faptul că un eu vorbește acum. Astfel, conform lui Benveniste, „timpul lingvistic este autoreferenţial” (Benveniste, 1971, p. 227): „prezentul” nu este altceva decât timpul în care eul vorbește. Aceasta este și perspectiva din care Benveniste integrează teoria actelor de vorbire propusă de Austin, integrând-o formelor subiectivității - spațiul comunicării de față nu ne permite o analiză mai detaliată a acestei recuperări. Reiterând concluzia lui Benveniste, „multe noțiuni din lingvistică, poate și din psihologie, vor apărea într-o lumină diferită dacă le vom restabili în cadrul discursului. $\mathrm{Cu}$ alte cuvinte, al limbii în măsura în care este asumată de omul care vorbește și în condiția intersubiectivității, singura care face posibilă comunicarea lingvistică" (Benveniste, 1971, p. 230). 
Teoria argumentării în sistemul limbii, propusă de Oswald Ducrot (Ducrot, 2009, passim), apare drept o nuanțare și o radicalizare a perspectivei lui Benveniste, care, după cum voi încerca să ilustrez, ne permite să analizăm o serie de fapte de limbă într-un mod pe care îl consider extrem de productiv. Spre deosebire de Benveniste, care tratează subiectivitatea discursivă - eul care vorbește - drept o entitate integră, un monolit, Ducrot o scindează în trei elemente diferite: vorbitorul empiric - entitatea întrupată care produce un enunț sau o înșiruire de enunţuri, locutorul - eul asumat, „responsabilul de enunț” reflectat prin mărcile persoanei I, și enunțiatorul - perspectiva din care este formulat un enunț, care poate fi a locutorului - dar nu neapărat; mai mult decât atât, după cum arată Ducrot în teoria sa asupra polifoniei, în același enunț pot fi prezenți mai mulți enunțiatori. Contextul în care își formulează Ducrot această teorie pornește tot de la constatarea, comună cu perspectiva propusă de Benveniste, Austin sau Heidegger, că a trata limbajul drept mecanism de transmitere a unei informații este, în ultimă instanță, nesatisfăcător: ceea ce facem atunci când vorbim manifestă o orientare intrinsecă spre interlocutorul nostru, o încercare de a-l influența într-un fel sau altul. Ducrot numește această caracteristică - pe care o atribuie limbii, nu doar vorbirii-argumentativitate. Vorbind unul cu altul, ceea ce încercăm să facem este să-i creăm interlocutorului nostru baze pentru a-și formula o concluzie, să-1 ghidăm spre o anumită concluzie. Respectiv, ceea ce primează este, pentru Ducrot, aspectul perlocuţionar al limbajului, nu cel ilocuționar, ca în teoria clasică a actelor de vorbire. Privind din această perspectivă, atunci când examinăm funcționarea limbajului, întrebarea ce ghidează demersul de cercetare ar fi care e lucrul de care locutorul încearcă să-și convingă destinatarul? ce concluzie încearcă să genereze locutorul în destinatar?

Pentru un asemenea tip de analiză, ,informația” prezentată într-un enunț trece pe un plan secundar. Primează orientarea intersubiectivă, argumentativă, exprimată în mărcile enunțării, ce capătă sens anume datorită orientării lor spre crearea unei concluzii în interlocutor. Ducrot integrează în acest tip de analiză şi teoria polifoniei pe care o propune: fiecare enunt, conform lui, se prezintă ca o mică dramă - sau un dialog - dintre câteva puncte de vedere prezente implicit. Chiar dacă locutorul este singular, enunţiatorii pot fi multipli.

Un prim exemplu ce ilustrează această teză este negația. În prezența formelor negative, avem de a face cu un punct de vedere al unui enunţiator 1 , reluat în enunt, și cu punctul de vedere al enunțiatorului 2, care constă în negarea celui propus de enunțiatorul 1 - o menținere a unei perspective (mișcarea 1) care este negată (mișcarea 2), dar pe care o putem discerne chiar dacă este negată. Putem observa enunțuri aparent simple în care detectăm urme ale mai multor enunțiatori - trei, patru sau chiar cinci. Adesea, funcționarea lor la nivel discursiv este implicită - și tocmai scoaterea la iveală a implicitului ne permite 
o înțelegere adecvată a felului în care funcționează discursul și subiectivitatea în care este acesta ancorat.

Voi oferi un exemplu simplu, prima strofă dintr-un poem de Domnica Drumea, Puritate (Drumea, 2014, p. 11):

ziua din care nu vreau să mă ridic

ca dintr-un coșciug de gheață

Înțelegerea unui asemenea fragment e facilitată de remarcile fundamentale ale lui Benveniste: fiecare discurs este ancorat într-o subiectivitate determinată și un prezent determinat al spunerii. Deci, într-o interpretare în cheia teoriei enunţării, putem înțelege primul vers ca spunând:

[acum e / asta e] ziua din care nu vreau să mă ridic

cu referința la prezentul spunerii aparent eliminată, dar observabilă în indicativul prezent al verbului. Discursul poetic, după cum sugerează Jacques Derrida (Derrida, 1991, p. 225), se caracterizează prin efectul de concizie eliminarea a tot ce e de prisos. Referința la acum-ul spunerii e subînțeleasă în însuși faptul spunerii.

Un al doilea aspect pe care îl putem remarca, atunci când urmărim felul în care se constituie subiectivitatea în acest fragment, derivă din analiza negației pe care o face Ducrot. Vocea poetică - locutorul - spune

nu vreau să mă ridic

Ce implică $n u$-ul din „nu vreau”? Răspundem „nu vreau”, de obicei, unei propuneri. „Nu vreau să mă ridic” e un răspuns la propunerea - sau îndemnul „Ridică-te!”. În însuși îndemnul ridică-te este prezentă o evaluare a faptului de a te ridica drept ceva pozitiv: ne amintim de îndemnul evanghelic al lui Iisus adresat paraliticului vindecat, de exemplu, ,ridică-te, ia-ți patul și umblă”. Faptul de a te ridica este conotat pozitiv - ca posibilitate de a face ceva, de a deveni activ. Refuzul prin „nu vreau să mă ridic” nu trebuie interpretat pur și simplu ca o descriere a unei stări de spirit a unui subiect izolat, dat fiind faptul că orice ocurență a discursului apare într-un context dialogic - pe fundalul unor enunţuri preexistente, deja sedimentate, și, în acelaşi timp, al prezenței alterității, chiar și numai imaginată. În însuşi enunţul „,nu vreau să mă ridic” este prezentă, implicit, poziţia unui alt enunțiator - un locutor care ar îndemna vocea poetică / subiectul locutor să se ridice, poziție pe care o putem numi enunțiatorul 1. În plus, atunci când avem de a face cu o orientare argumentativă, este prezent implicit ceea ce Ducrot numește, preluând termenul aristotelic, topos: motivul din care concluzia spre care îndeamnă un enunţiator este prezentată drept ceva ce ar trebui să fie acceptat de destinatar. În cazul nostru, verbul a te ridica poartă, la nivel lexical, urma unei evaluări pozitive a acțiunii de a te ridica: ,a te ridica” este ceva activ și dinamic. Acest fenomen poate fi conceptualizat cu ajutorul unui alt termen propus de Ducrot, cel de enunțiator 
lexical: în însuși sensul unui cuvânt este inclusă o evaluare a faptului la care se referă acesta. Argumentativitatea operează, așadar, nu doar la nivelul discursului, ci și, mai fundamental, la cel al limbii, fiind prezentă în însuși sensul cuvintelor utilizate, chiar dacă, aparent, ele sunt neutre. Respectiv, în micul dialog reflectat în enunțul „,nu vreau să mă ridic” apare încă un enunțiator - lexical, în termenii lui Ducrot - pe care îl vom numi enunțiator 2, implicit în sensul verbului a te ridica. Al treilea enunțiator, perspectiva căruia șii-o asumă locutorul - vocea poetică răspunde îndemnului, refuzându-1, cu negația „nu”: „nu vreau să mă ridic”. Subiectivitatea poetică se manifestă, din primul vers, ca refuz abrupt al unui îndemn aparent binevoitor - de a deveni activă, de a-și depăși o condiţie de pasivitate.

Citind al doilea vers tot în cheia orientării intrinsec argumentative a discursului, întrebarea care ne poate ghida demersul analitic e de ce ar spune cineva așa ceva? ce ar încerca să facă, spunând ceea ce spune? Comparația

ca dintr-un coșciug de gheață

funcționează nu pur și simplu ca o descriere sau caracterizare a ,zilei” din care subiectul locutor „nu vrea să se ridice”, ci ca mod de a explica lipsa dorinței de a se ridica. Putem să ne amintim, de exemplu, motivele din care, atunci când un explorator polar obosește, nu e recomandat să se întindă în zăpadă să se odihnească: hipotermia se manifestă inițial ca lipsa dorinței de a te mișca. Un coșciug de gheață, în enunţul poetic pe care îl examinăm acum, sugerează același lucru: ,ziua din care îmi propuneți să mă ridic, și în care sunt întinsă, e rece ca un coșciug de gheaţă din care nu mai vreau să mă ridic". Avem un nou topos sedimentat în enunț: răceala care anulează orice dorință de a te mișca, făcând indezirabil - sau chiar imposibil - însuși efortul de a te ridica: avem un ,nu vreau să mă ridic” care este practic echivalent cu un ,nu pot să mă ridic”, dar asumat de locutor ca refuz, nu ca imposibilitate: ultima putere a locutorului este cea de a spune „nu vreau”, enunț prin care se și constituie ca subiectivitate a cărei singură formă de activitate este refuzul. Putem atribui acest topos unui nou enunțiator, pe care l-am putea numi enunțiator 4: vocea care oferă motive sau explicaţii pentru refuzul prin care se constituie eul locutor.

Un asemenea tip de lectură, care urmărește mărcile subiective ale enunțării și privește enunţul ca ancorat într-o subiectivitate vie, ne permite să scoatem la suprafaţă multiple straturi implicite în enunțuri aparent simple. Raportarea unui text la sursele lui subiective, la spunerea care își lasă urma în spus, permite reconstituirea subiectivităţii vii care a fost originea lui și care este, în fapt, neglijată în tipul obișnuit de lectură ce atrage atenția doar asupra conținutului informativ, și chiar în interpretările semiotice răspândite în anumite forme ale criticii literare. Subiectivitatea operează implicit în fiecare act discursiv, iar explicitarea structurilor ei ne ajută să înțelegem și felul în care o face, punând sub semnul întrebării lucruri pe care le luăm ca fiind de la sine înțelese sau, din contra, ajutându-ne să observăm 
lucruri evidente, dar pe care avem tentația să le neglijăm. În primul rând, faptul că subiectivitatea se constituie dialogic și discursiv: simplul fapt al ,simţirii de sine" sau al prezenței unui afect încă nu echivalează cu constituirea unui subiect „plin”. Subiectul se constituie și se identifică doar prin raportare la alt subiect - ca în cazul fragmentului de text pe care l-am analizat, în care subiectul se constituie ca subiect printr-un refuz exprimat verbal, un „,nu vreau să mă ridic” ce definește vocea poetică drept una a blocării, negării, rămânerii într-un spațiu afectiv rece și mort care face imposibil orice efort, inclusiv cel aparent simplu de a se ridica. În al doilea rând, subiectivitatea locutorului se constituie în prezentul enunţării - în însuși momentul spunerii; nu este ceva dat, ci continuu reinstituită de discurs. În al treilea rând, subiectivitatea nu este un monolit, ci poartă în sine urmele vocilor celorlalți - ale altor enunţiatori care bântuie discursul, fiind prezenți în mod implicit. Remarcarea acestor aspecte devine posibilă atunci când citim un text încercând să urmărim stratul lui perlocuţionar - efectul urmărit de locutor - în detrimentul unei abordări bazate strict pe conținut.

\section{Referințe bibliografice:}

1. BENVENISTE, Emile. Subjectivity in Language. În: Emile Benveniste, Problems in General Linguistics, University of Miami Press, 1971.

2. DERRIDA, Jacques. Che cos'è la poesia. În A Derrida Reader. Between the Blinds. Editat de Peggy Kamuf. Columbia University Press, 1991, pp. 221-237.

3. DRUMEA, Domnica. Vocea. Charmides, 2014.

4. DUCROT, Oswald. Slovenian Lectures. Introduction into Argumentative Semantics. Pedagogski Institut, Ljublana, 2009.

5. HEIDEGGER, Martin. On the Way to Language. Harper \& Row, 1971.

Notă: Articolul a fost realizat în cadrul proiectului de cercetare 20.80009.1606.01 Valorificarea științifică a patrimoniului lingvistic național în contextul integrării europene, Institutul de Filologie Română „B.P.-Hasdeu” al MEC. 